UDK 577.13:582

\title{
PRELIMINARY PHYTOCHEMICAL SCREENING FOR SECONDARY METABOLITES IN LEAVES AND BARK OF 25 BROADLEAF DECIDUOUS SPECIES
}

\author{
Preliminarna fitohemijska analiza sekundarnih metabolita u listovima i kori 25 \\ lišćarskih vrsta \\ Fatima Pustahija ${ }^{1}$, Neđad Bašić ${ }^{1}$
}

\begin{abstract}
Plants produce a numerous and diverse secondary metabolites, organic compounds which are not essential and do not participate directly in the growth and development, but may have very important role in their adaptation and adjustment to particular environmental conditions. For humans, secondary metabolites are very important in medicine, pharmacology, food and cosmetics industries. The presence of eight types of secondary metabolites (anthocyanins, coumarins, emodins, fatty acids, phenols, saponins, steroids and tannins) in water extracts of leaves and barks of 25 broadleaf deciduous species from 15 families was qualitatively investigated by rapid phytochemical screening methods. According to literature data, in this study for the first time is determined the presence of six types of secondary metabolites in analyzed dendro species: anthocyanins in one species; both coumarins and phenols in five species; emodins in six species; saponins in eight species; and tannins in four species. Particular attention in further research should be given to Fagus sylvatica L., Populus tremula L., Quercus petraea (Matt.) Liebl., Robinia pseudoacacia L. and Sorbus aria (L.) Crantz. Since preliminary results of this study are promising it would be desirable both to identify active compounds and assess their potential antimicrobial and antioxidant activities.
\end{abstract}

Key words: anthocyanins, Bosnia and Herzegovina, coumarins, emodins, phenols, saponins, tannins.

\section{INTRODUCTION - Uvod}

People constantly have been explored their environment with special emphasis on plants and their properties. This has resulted in the use of a large number of plants, especially in healthcare which medicinal values lay in their phytochemical composition and physiological activities. Namely, plants produce a huge and diverse range of secondary metabolites (SMs), bioactive organic compounds which do not participate directly in their growth and development, but may have very important role in the adaptation and adjustment to particular environmental conditions. Secondary metabolites are

\footnotetext{
${ }^{1}$ Faculty of Forestry, University of Sarajevo, Zagrebačka 20, 71000 Sarajevo, BiH
} 
distributed in a limited number of taxonomic plant groups, belonging to specific groups of chemical compounds and synthesized under specific conditions and, in many cases, with unclear role and contribution to the plant organism. Their concentrations vary between species, individuals and tissues but also from season to season (GOTTLIEB 1990; WINK 1990, 1999; WINK AND WATERMAN 1999; MíkA ET AL. 2005; KOCHE 2010; HARINI ET AL. 2014, TIWARI AND RANA $2015 ;^{2}$ ).

According to FORESTRY COMMISION (2001), only $25 \%$ of felled tree is transformed into timber, and remaining plant material (usually rich with SMs and plant fibres) is relatively unexplored and unexploited. In fact, that large quantity of tree residues can present source for searching, isolation and identification of some new active compounds, and for massive production of some SMs since it is considered that, in the realm of wood processing, everything that is not a structural polysaccharide or lignin is secondary metabolite.

In order to "add values" to some tree species the presence of eight types of SMs in 25 broadleaf deciduous species was investigated by rapid phytochemical screening methods in this study.

\section{MATERIAL AND METHODS - Materijal i metode}

\section{Identification and sampling of plant material}

Plant material of 25 broadleaf deciduous species from 15 families was collected in July 2013. in natural populations near Sarajevo (B\&H), in

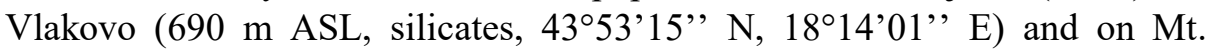

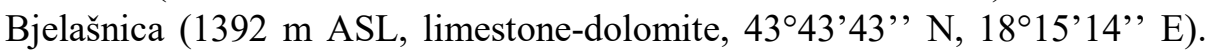
Taxonomic identification of the plants was carried out during field work. Leaves and barks (free from diseases) were separated immediately into paper bags. Then, the plant material was washed thoroughly with running tap water and rinsed with distilled water, and was drying during 10 days in the overshadowed at room temperature in a well ventilated room. Thereafter, dried material is grounded in mixer and powder is packed in plastic bags and stored to the implementation of the extraction process.

\section{Chemicals}

All used chemicals were of analytical grade.

\section{Preparation of extracts}

To obtain the aqueous extracts shredded materials were transferred to glass beakers, with adding $50 \mathrm{~mL}$ of distilled water, boiled 30 minutes at 50 ${ }^{\circ} \mathrm{C}$ in a water bath, and filtered through Whatman No.1 filter paper. Then, filtrate was centrifuged at 2,500 rpm for 15 minutes and stored in sterile glass

\footnotetext{
${ }^{2} \mathrm{https}$ //secure.fera.defra.gov.uk/treechemicals/review/index.cfm, accessed: 02.09.2016.
} 
bottles at $5{ }^{\circ} \mathrm{C}$ to perform phytochemical screening (modified SAViTHRAMmA ET AL. 2011, modified SUBHASHINI DEVI ET AL. 2014).

\section{Phytochemical screening}

Preliminary qualitative phytochemical screenings of water extracts were carried out with the following methods:

Anthocyanins: $2 \mathrm{~mL}$ of $2 \mathrm{~N}$ hydrochloric acid and $2 \mathrm{~mL}$ of ammonia were added to $2 \mathrm{~mL}$ of aqueous extract. Discoloration of red-pink colour in the blue-violet indicates the presence of anthocyanins (PARIS AND MOYSE 1969).

Coumarins: $3 \mathrm{~mL}$ of $10 \%$ sodium hydroxide were added to $2 \mathrm{~mL}$ of aqueous extract. The presence of coumarins is indicated by formation of yellow colour (RIZK 1982).

Emodins: $2 \mathrm{~mL}$ of ammonium hydroxide and $3 \mathrm{~mL}$ of benzene were mixed with $2 \mathrm{~mL}$ of aqueous extract. Emodins are indicated in the case of appearance of red colour (RIZK 1982).

Fatty acids: $5 \mathrm{~mL}$ of ether were added to $0.5 \mathrm{~mL}$ of water extract. Solution pours out on filter paper and allows evaporating and drying. Transparency on filter paper indicates the presence of fatty acids (AYOOLA 2008).

Phenols: $2 \mathrm{~mL}$ of $2 \%$ solution of iron (III) chloride mixed with $2 \mathrm{~mL}$ of aqueous extract. Appearance of blue-green or black coloration indicates the presence of phenols (SUBHASHINI DEVI ET AL. 2014).

Saponins: $5 \mathrm{~mL}$ of water extract was diluted with $20 \mathrm{~mL}$ of distilled water and agitated for 15 minutes. The presence of saponins is indicated by foam formation (KUMAR ET AL. 2009).

Steroids: $1 \mathrm{~mL}$ of the aqueous extract was dissolved in $10 \mathrm{~mL}$ of chloroform followed by addition, by sides of the test tube, $10 \mathrm{~mL}$ of concentrated sulphuric acid. The presence of steroids is indicated when the upper (chloroform) layer turns red and lower (sulphuric acid) layer showed yellow with green fluorescence (GIBBS 1974).

Tannins: a few drops of $1 \%$ lead acetate were added to $2 \mathrm{~mL}$ of water extract. Appearance of yellowish precipitate indicates the presence of tannins (TREARE AND EVANS 1985).

\section{RESULTS AND DISCUSSION - Rezultati i diskusija}

Using various phytochemical screening tests it is possible to detect bioactive principles, and facilitate quantitative estimation and qualitative separation of active compounds (VARADARAJAN ET AL. 2008). The phytochemical screening and qualitative estimation of 25 analyzed broadleaf deciduous species showed that their leaves were rich in phenols and fatty acids followed by saponins, tannins and emodins, with no steroids (Table 1). To our knowledge, emodins were observed for the first time in six species. Barks were rich in tannins, phenols, fatty acids and saponins, but without anthocyanins, emodins and steroids (Table 1). Of the 25 analyzed species in this study, according to available literature data, for some of them the 
presence of SMs either has not been investigated at all (Acer obtusatum Waldst \& Kit. ex Willd., Quercus petraea L.) or just for one or two SMs (Crataegus monogyna Jacq., Euonymus europaeus L., Prunus avium (L.) L., Pyrus pyraster (L.) Burgsd., Robinia pseudoacacia L., Sorbus aria (L.) Crantz, S. domestica L. and S. torminalis (L.) Crantz) until today. From 117 obtained positive tests, 69 of them were observed in bark extracts. The largest number of newly found SMs, to our knowledge, was present in $R$. pseudoacacia (4), followed by Fagus sylvatica L., Populus tremula L., $Q$. petraea and Sorbus aucuparia L. (3), and A. obtusatum, A. tataricum L., C. monogyna, Daphne mezereum L., Fraxinus ornus L. and P. pyraster (2).

Anthocyanins, one of the classes of flavonoids and nonphotosynthetic pigments, are important plant pigments responsible for the red, pink, purple, and blue colours in plants. They have different functional roles in plants, as: antioxidants and sunscreens, mediators of reactive oxygen species-induced signalling cascades, chelating agents for metals and/or metalloids and delayers of leaf senescence (LANDI ET AL. 2015). Many studies have shown that these pigments as strong antioxidants prevent the development of heart disease and cancers have anti-inflammatory activity, preventing bacterial infection etc. (SEERAM 2008, and references in the article). Anthocyanins are found in leaves extracts in four species and, for the first time, in D. mezereum. The data for presence of anthocyanins in analyzed species found in the literature have shown a certain variation in comparison to the results obtained during this study (LINDEBERG 1971, MARKHAM 1989, JePPSSON 1995, Wu ET AL. 2002, HeINRICH 2005, KIM ET AL. 2005, MAMdOH 2010).

Coumarins and their derivatives are widely distributed in nature, with very important roles in plant defence mechanisms against herbivores and microorganisms. Humans use them as anticoagulant, antioxidant, antimicrobial, anticancer, anti-diabetic, analgesic and anti-inflammatory agents, and as vitamin $\mathrm{K}$ antagonist (MIRUNALINI AND KRISHNAVENI 2011, MATOS 2015). In this study, coumarins were observed in seven species of which at six, to our knowledge, for the first time: C. monogyna, E. europaeus, $F$. sylvatica, P. tremula, Q. petraea and $R$. pseudoacacia (Table 1). However, in this study has not confirmed the presence of coumarins in other analyzed species, although there are reports in the literature (MARINOVA ET AL. 1994, PeARCE 2000, Lutsenko et Al. 2006, Stollova et AL. 2007, YANG et AL. 2009, MAMDOH 2010, MARKOVIĆ ET AL. 2010).

Emodins have multiple ecological functions in higher plants (protect against herbivores, pathogens, competitors and extrinsic abiotic factors) and represent a very useful group of SMs for humans, as laxative compounds and anti-inflammatory, antimicroorganism and antifeedant agents (IZHAKI 2002, SUBHASHINI DEVI ET AL. 2014). They were present in the bark of five analyzed species: C. monogyna, F. ornus, $P$. tremula, $P$. avium and $S$. aria, and in the leaves of Rhamnus fallax Boiss. (Table 1). Since in the literature are not found 
data for presence of emodins in analyzed broadleaf deciduous species in this study, these data are the first published for those species.

Fatty acids have important functions in plants, especially as an important source of reserve energy and essential components of membrane lipids, as well as in defence against pathogens (KACHROO AND KACHROO 2009). In humans, they participate in regulation of membrane structure and function; regulation of intracellular signalling pathways, transcription factor activity, and gene expression; and regulation of the production of bioactive lipid mediators (CALDER 2015). The presence of fatty acids, in this study, was observed in 15 species (Table 1), and the results were completely consistent with the literature data (LINDEBERG 1971, LEVITT 1980, MARKHAM 1989, AYERS ET AL. 1996, PUKACKA AND CZUBAK 1998, Al-Taweel 2000, Kostova 2001, StRANSKY ET AL. 2001, LUTSENKO ET AL. 2006, CODREANU ET AL. 2007, BRINDZA ET AL. 2009, MARKOVIĆ 2010, ČEKSTERYTÉ 2012, ŽEPIČ ET AL. 2013).

Phenols, the most important group of SMs in plants, are included in many physiological processes in plants and represent adaptive features developed during plant evolution. Also, they are of human interest because of their wide range of functions performed as: a disinfectant and raw materials for the production of medicaments, herbicides and cosmetics (LATTANZIO ET AL. 2006). Phenols were observed in 16 analyzed species, where 14 of them possessed phenolic compounds in leaves, and 13 species in the bark (Table 1). Although phenols are one of the most researched SMs in plants (PETRYNIAK ET AL. 1981, MARKHAM 1989, HAMILTON ET AL. 2004, HeINRICH 2005, LUTSENKO ET AL. 2006, Olivier ET AL. 2006, RimpapA ET AL. 2007, Conforti ET AL. 2008, Hegab-GHareib 2010, Maleš ET AL. 2010, Zoobi-Mohd 2010, KylLI 2011, MANOJLOVIC ET AL. 2012, OlSZEWSKA 2012), in this study for the first time phenols are determined in five species: A. tataricum, F. sylvatica, $P$. tremula, Q. petraea and S. aria (Table 1).

Saponins are stored in plant cells as inactive precursors which are very easily converted to the biologically active antibodies in response to pathogen attack, playing a very important role in allelopathic defence against microorganisms, fungi and herbivores. For humans they have significant commercial values, and are used as medicines, detergents, sweeteners, food additives and cosmetics (MERT-TÜRK 2006, Koul 2008). In this study, saponins are observed in 14 species, of which the newly discovered in eight: A. obtusatum, A. tataricum, D. mezereum, F. ornus, $R$. pseudoacacia, Sambucus nigra L., S. aria and S. aucuparia (Table 1). It is noticed, based on data from the available literature, that in this study is not confirmed the presence of saponins in three species (AYERS ET AL. 1996, AL-TAWEEL 2000, Kostova 2001, Pfeiffer et al. 2003, LutSenKo et AL. 2006, Olivier et AL. 2006, AleXANDER 2009, BRINDZA ET AL. 2009, AHMET 2011).

Plant steroids are a class of lipids with different functions, which play an important role in a number of biological processes: from growth and development to resistance to stress (BISHOP AND KONCZ 2002). The 
examination on the presence of steroids in the leaves and bark of analyzed species were negative. This is in agreement with many literatures reporting of steroids absence in plants, except for $P$. avium which possess steroids in leaves (EL-TAHAWI 1983).

Tannins, phenolic compounds of high molecular weight, are widely distributed SMs in plant flora, mainly located in a bark. Plants produce them as protective substances against herbivores, insects and other pests. Humans use tannin rich plants as antioxidant, antimicrobial, anti-inflammatory and healing agents in a number of diseases, and as astringent (BHANDARY ET AL. 2012, DoughaRI 2012, SAVITHRAMmA ET AL. 2011, SubHASINI DEVI ET AL. 2014, GUETAFF ET AL. 2016). Tannins presence was confirmed in 16 analyzed species, of which for the first time in four: A. obtusatum, P. pyraster, $Q$. petraea and $S$. domestica (Table 1). In this study has not confirmed the presence of tannins in four species, although it is noted in some articles (Lindeberg 1971, Rowe ANd Conner 1979, Markham 1989, Palta 1992, Ayers et AL. 1996, Kostova 2001, KIM ET AL. 2005, ANDRÉ ET AL. 2006, OlivieR ET AL. 2006, BRINDZA ET AL. 2009, MALEŠ ET AL. 2010, MARKović 2010, AHMET 2011, GUZIK 2012).

The obtaining of diverse results in comparison to literature data probably lie in the use of different both qualitative methods for determining of SMs and solvent of extraction, and plant individuals' exposure to different ecological conditions. Also, according to WINK (1999), accumulation and concentration of SMs is not uniform for different plant parts, individuals and species, and it is result of very complex interactions between biosynthesis, transport, storage and degradation of certain SM.

The results of this study, at the same time, represent valuable data source for further more detailed investigations of some here analyzed broadleaf deciduous species, and increase potential of commercial values of certain broadleaf deciduous species.

\section{CONCLUSIONS - Zaključci}

The aim of present study was to examine qualitative composition of SMs in leaves and bark of 25 broadleaf deciduous species from 15 families. Preliminary phytochemical screening reveals the presence of various SMs in analyzed species, mainly distributed in bark. The results suggest that this approach of tree species research should continue and expand with use of other qualitative and some quantitative methods, which are more sophisticated and precise. Also, this preliminary study draws attention to the need for further studies of isolation and identification of active compounds in species of interest, and for the assessing of their potential antimicrobial and antioxidant activities. 


\section{REFERENCES - Literatura}

Aнmet A. (2011): Development of quality profile of Salix caprea and its aromatic water. PhD Thesis, University of Kashmir Srinagar, Kashmir, Pakistan.

AleXANDER J. (2009): Saponins in Madhuca longifolia L. as undesirable substances in animal feed. The EFSA Journal 979: 1-36.

Al-TAWEel M. (2000): Phytochemical and biological studies of some Clematis species growing in Saudi Arabia. PhD Thesis, Department of Pharmacognosy at the College of Pharmacy King Saud University, Saudi Arabia.

ANDRÉ O, VOLLENWEIDER P, GÜNTHARDT-GOERG MS. (2006): Foliage response to heavy metal contamination in Sycamore Maple (Acer pseudoplatanus L.). For. Snow Landsc. Res. 80(3): 275-288.

AyERS AC, BARRETT RP, CHEEKE PR. (1996): Feeding value of tree leaves (hybrid popular and black locust) evaluated with sheep, goats, and rabbits. Animal Feed Science and Technology 57: 51-62.

Ayoola Ga, Coker hab, Adesegun SA, Adepoju-Bello Aa, Obaweya K, EZENNIA EC, AtANGBAYILA TO. (2008): Phytochemical screening and antioxidant activities of some selected medicinal plants used for malaria therapy in South Western Nigeria. Trop J Pharm Res 7(3): 1019-1024.

BHANDARY SK, KUMARI NS, BHAT VS, SHARMILA KP, BEKAL MP. (2012): Preliminary phytochemical screening of various extracts of Punica granatum peel, whole fruit and seeds. Nitte Univ J Health Sci 2(4): 3438.

BISHOP GJ, KONCZ C. (2002): Regulation of transcript levels of Arabidopsis chtochrome P450 grnrs involved in brassinosteroid biosynthesis. Plant Physiology 130: 504-513.

BRINDZA P, KLIMENKO SV, GRIGORIEVA O, BRINDZA J, TOTH D. (2009): Biological and commercial characteristics of Cornelian Cherry (Cornus mas L.) population in the Gemer region of Slovakia. International Symposium on Pomegranate and Minor Mediterranean Fruits, Vol. 818, Adana,Turkey: p. 85-93.

CALDER PC. (2015): Functional roles of fatty acids and their effects on human health. J Parenter Enteral Nutr. 39(1 Suppl): 18S-32S.

ČEKSTERYTĖ V. (2012): Composition and content of fatty acids in beebread of various floral origin, collected in Lithuania and prepared for storage in different ways. Cheminè technologija 2: 60.

CODREANU M-V, ISTUDOR V, DOCIU N. (2007): Acer tataricum L. seeds - a new convenient source of gamma-linolenic acid., Acta Chromatographica 19: 238-245.

Conforti F, Ioele G, Statti G, Marrelli M, Ragno G, Menichini M. (2008): Antiproliferative activity against human tumor cell lines and toxicity test 
on Mediterranean dietary plants. Food and chemical toxicology 46: 33253332.

DoughaRI JH. (2012): Phytochemicals: extraction methods, basic structures and mode of action as potential chemotherapeutic agents. In: Rao V. (Ed), Phytochemicals - A global perspective of their role in nutrition and health, ISBN: 978-953-51-0296-0, InTech, DOI: 10.5772/26052.

EL-TAHAWI BS, Diab MA, HABIB MA, ALY MA. (1983): Steroid composition of the Egyptian peach oir. Journal of Agricultural Research 6: 303-319.

FORESTRY COMMISSION (2001): Forestry Statistics 2001. A compendium of statistics about woodland, forestry and primary wood processing in the UK. Forestry Commission, Edinburgh.

GIBBS RD. (1974): Chemotaxonomy of flowering plants. Vol.1, McGill Queen's University Press, Montreal and London.

GotTlieB OR. (1990): Phytochemicals: differentiation and function. Phytochemistry 29: 1715-1724.

Guettaf S, AbidLI N, KaRICHe S, BellebciR L, BouRiche H. (2016): Phytochemical screening and antioxidant activity of aqueous extract of Genista saharae (Coss. \& Dur.). Der Pharmacia Lettre 8 (1): 50-60.

GuZIK G. (2012): EPR study on sugar radicals utilized for detection of radiation treatment of food. Nukleonika 57: 545-549.

Hamilton JG, Zangerl AR, Berenbaum MR, Sparks JP, ELICH L, Eisenstein A, DELUCiA EH. (2004): Insect herbivory in an intact forest understory under experimental $\mathrm{CO}_{2}$ enrichment. Oecologia 138: 566-573.

Harini K, JeRLinShowmya J, Geetha N. (2014): Phytochemical constituents of different extracts from the leaves of Chromolaena odorata (L.) King and Robinson. International Journal of Pharmaceutical Sciences and Business Management 2(12): 13-20.

HEgab MM, GHAREIB HR. (2010): Antioxidative effects of acetone fraction and vanillic acid from Chenopodium murale L. on tomato plant. Weed Biol Manag 10: 64-72.

HEINRICH M. (2005): Co-ordinator of the local food-nutraceuticals consortium. Understanding local Mediterranean diets: a multidisciplinary pharmacological and ethnobotanical approach. Pharmacological Research 52: 353-366.

IZHAKI I. (2002): Emodin - a secondary metabolite with multiple ecological functions in higher plants. New Phytologist 155(2): 205-217.

JEPPSSON N. (1995): The effect of cultivar and cracking on fruit quality in Black Chokeberry (Aronia melanocarpa) and hybrids between chokeberry and rowan (Sorbus). Gartenbauwissenschaft 65: 93-98.

KACHROO A, KACHROO P. (2009): Fatty acid-derived signals in plant defense. Annual Review of Phytopathology 47: 153-176.

Kim DO, HeO HJ, Kim YJ, YANG HS, Lee CZ. (2005): Sweet and sour cherry phenolics and their protective effects on neuronal cells. Journal of Agricultural and Food Chemistry 53: 9921-9927. 
Koche D, Shirsat R, ImRan S, Bhadange DG. (2010): Phytochemical screening of eight traditionally used ethnomedicinal plants from akola district (MS) India. International Journal of Pharma and Bio Sciences 1(4): 253-256.

Kostova I. (2001): Fraxinus ornus L. Fitoterapia 72(5): 471-480.

KOUL O. (2008): Phytochemicals and insect control: an antifeedant approach. Critical reviews in plant sciences 27: 1-24.

Kumar a, Ilavarasn R, Jayachandran T, Decaraman M, Aravindhan P, PADMANABAN N, KRISHNAN MRV. (2009): Phytochemical investigation on a tropical plant. Pak J Nutri 8: 83-85.

KYLLI P. (2011): Berry phenolics: isolation, analysis, identification, and antioxidant properties. PhD Thesis, University of Helsinki, Department of Food and Environmental Sciences Food Chemistry. Helsinki, Finland.

LANDI M, TATTINI M, GoulD KS. (2015): Multiple functional roles of anthocyanins in plant-environment interactions. Environmental and Experimental Botany 119: 4-17.

LATTANZIO V, LATTANZIO VMT, CARDINALI A. (2006): Role of phenolics in the resistance mechanisms of plants against fungal pathogens and insects. Phytochemistry: Advances in Research: 23-67.

LEVITT J. (1980): Chilling, freezing, and high temperature stresses. Responses of plants to environmental stresses, Vol. 1. Academic Press, London, England.

LINDEBERG G. (1971): Aromatic substances in leaves of Populus tremula as inhibitors of mycorrhizal fungi. Physiologia Plantarum 25: 122-129.

LUTSENKO Y, BYLKA W, MATŁAWSKA I, DARMOHRAY Y. (2006): Hedera helix as a medicinal plant. Herba Polonica 56(1): 83-96.

MALEŠ Ž, KREMER D, GaŠPAR RANDIĆ Z, RANDIĆ M, HAZleR PILEPIĆ K, BojIć M. (2010): Quantitative analysis of glucofrangulins and phenolic compounds in croatian Rhamnus and Frangula species. Acta biologica Cracoviensia series botanica 52: 108-113.

MAmDoH M. (2010): Benzoic acid metabolism in Sorbus aucuparia cell suspension cultures. PhD Thesis, Fakultät für Lebenswissenschaften der Technischen Universität Carolo-Wilhelmina, Braunschweig, Germany.

MANOJLOVIC N, MAŠKOVIĆ P, VASILJEVIĆ P, JELIĆ R, JUSKOVIĆ M, SOVRLIĆ M, MANDIĆ L, RADOJKOVIĆ M. (2012): HPLC analysis, antimicrobial and antioxidant activities of Daphne cneorum L. Hemijska industrija 66: 709716.

MARINOVA E, YANISHLEVA N, Kostova I. (1994): Antioxidative activity of phenolic acidson triacylglycerols and fatty acid methyl esters from olive oil. Institute of Organic Chemistry with Center of Phytochemistry, Sofia, Bulgaria, 56(2), p. 139-145.

MARKHAM KR. (1989): Plant phenolics. In: Harborne JB. (ed.), Methods in plant biochemistry, Vol. 1, Academic Press, London, UK, p. 197-235. 
Marković M, Matović M, Pavlović D, Zlatković B, MaRković A, Jotić B, STANKOV V. (2010): Resources of medicinal plants and herbs collector's calendar of Pirot County (Serbia). Biologica Nyssana 1: 9-21.

Matos mJ, Santana L, URiarte E, Abreu OA, Molina E, Yordi EG. (2015): Coumarins - An Important Class of Phytochemicals. In: Rao AV, Rao LG (Eds), Phytochemicals - Isolation, Characterisation and Role in Human Health, InTech, http://dx.doi.org/10.5772/59982, p. 113-140.

MERT-TÜRK F. (2006): Saponins versus plant fungal pathogens. Journal of Cell and Molecular Biology 5: 13-17.

Míka V, KubÁŇ V, Klejdus B, OdstrčIlová V, NerušIl P. (2005): Phenolic compounds as chemical markers of low taxonomic levels in the family Poaceae. PLANT SOIL ENVIRON. 51(11): 506-512.

MIRUNALINI S, KRISHNAVENI M. (2011): Coumarin: a plant derived polyphenol with wide biomedical applications. International journal of PharmTech Research 3: 1693-1696.

Olivier A, VollenWAider P, Gunthardt-Goerg M. (2006): Foliage response to heavy metal contamination in Sycamore Maple (Acer pseudoplatanus L.). Forest, snow and landscape research 80: 275-288.

OLSZEWSKA MA. (2012): In vitro antioxidant activity and total phenolic content of the inflorescences, leaves and fruits of Sorbus torminalis (L.) Crantz. Acta Poloniae Pharmaceutica 68: 945-953.

PALTA JP. (1992): Mechanisms for obtaining freezing stress resistance in herbaceous plants. In: Plant Breeding in the 1990s. Proceedings of a symposium held at North Carolina State University, p. 219-250.

PARIS R, MOYSE H. (1969): Precis de matiere medicinale. Paris: Masson.

PEARCE R. (2000): Decay development and its restriction in trees. Journal of arboriculture 26: 1.

Petryniak J, Janusz M, Markowska E, LISOWSKa E. (1981): Purification of the Euonymus europaeus lectin by affinity chromatography on the desialized MN blood group glycoprotein, and lectin NH2-terminal analysis. Acta Biochimica Polonica 28: 267-273.

Pfeiffer B, Alt S, Hein B, Schulz C, Kollar A. (2004): Investigations on alternative substances for control of apple scab - Results from Conidia germinating tests and experiments with plant extracts. Proceeding from $11^{\text {th }}$ International Conference on Cultivation Technique and Phytopathological Problems in Organic Fruit-Growing. Fördergemeinschaft Ökologischer Obstbau, Weinsberg, Germany, 101107.

PUKACKA S, CZUBAK A. (1998): The effect of desiccation on viability and membrane lipid composition of Acer pseudoplatanus seeds. Acta societatis botanicorum Poloniae 67: 249-252.

RIMPAPA Z, TOROMANOVIĆ J, TAHIROVIĆ I, ŠAPČANIN A, SOFIĆ E. (2007): Total content of phenols and anthocyanins in edible fruits from Bosnia. Bosnian journal of basic medical sciences 7: 117-120. 
RIZK AM. (1982): Constituents of plants growing in Qatar. Fitoterapia 52: 3542.

ROWE J, CONNER A. (1979): Extractives in eastern hardwoods - A review. General Technical Report FPL 18. Forest Products Laboratory, Forest Service, US Department of agriculture Madison, Wisconsin, USA, p. 72.

SAVITHRAMMA N, LINGA RAO M, SUHRULATHA D. (2011): Screening of medicinal plants for secondary metabolites. Middle-East J Sci Res 8(3): 579-584.

SeERAM NP. (2008): Berry fruits: compositional elements, biochemical activities, and the impact of their intake on human health, performance, and disease. J Agric Food Chem 56(3): 627-629.

Stollova A, Wilker M, Stoyanova A, Krastanov A, StancheV V. (2007): Antioxidant activity of extract from elder flower (Sambucus nigra L.). Herba Polonica 53: 45-54.

StRÁNSKÝ K, VALTEROVÁ I, FiedleR P. (2001): Nonsaponifiable lipid components of the pollen of elder (Sambucus nigra L.). Journal of Chromatography A 936: 173-181.

SubHAShinI DeVI P, SatyanaRayana B, TARakeswara NaIdU M. (2014): Phytochemical screening for secondary metabolites in Boswellia serrata Roxb. and Wrightia tinctoria (Roxb.) R.Br. Not Sci Biol 6(4): 474-477.

TIWARI R, RANA CS. (2015): Plant secondary metabolites: a review. International Journal of Engineering Research and General Science 3(5): 661-670.

TREARE GE, Evans WC. (1985): Pharmacognosy. $17^{\text {th }}$ edition, Bahive Tinal, London, p. 149.

Varadarajan P, Rathinaswamy G, AsiRVatahm D. (2008): Antimicrobial properties and phytochemical constituents of Rheo discolor. Ethnobotanical Leaflet 12: 841-845.

WINK M, WATERMAN PG. (1999): Chemotaxonomy in relation to molecular phylogeny of plants. Annual Plants Reviews 2: 300-341.

WINK M. (1990): Physiology of secondary product formation in plants. In: Charlwood BV, Rhodes MJC (Eds), Secondary products from plant tissue culture, Clarendon Press, Oxford, p. 23-41.

WINK M. (1999): Biochemistry of plant secondary metabolism. Annual Plant Reviews 2, Sheffield Academic Press, London, UK.

WU X, CAO G, PRIOR RL. (2002): Absorption and metabolism of anthocyanins in elderly women after consumption of elderberry or blueberry. Journal of Nutrition 132: 1865-1871.

Yang L, Wang S, Zhao Y, LiU K, Wang X, Yang Y. (2009): Chemical constituents from Clematis delavayi var. spinescens. Molecules 14: 44334439.

Zoobi J, MoHD A. (2010): Two new phenolic compounds from the flowers of Salix caprea. International Research Journal of Pharmacy 2: 138-141.

ŽEePIČ V, ERIKA Š, KoRošEC R, HANČIČ A, PRIMOŽ O, POLJANŠEK I. (2013): Influence of drying conditions on thermal and morphological behavior of 
microfibrilated and nanofibrilated cellulose. COST Action FP 0901

"Analytical techniques for biorefineries"-Tulln, Austria, p. 8-9.

\section{SAŽETAK}

Biljke proizvode brojne i raznolike sekundarne metabolite, organska jedinjenja koja nisu esencijalna i direktno ne sudjeluju u rastu i razviću, ali koja mogu imati vrlo važnu ulogu u adaptaciji i prilagodbi biljaka određenim okolišnim uvjetima. Za ljude su sekundarni metaboliti vrlo važni u medicini, farmakologiji te industriji hrane i kozmetike. Prisutnost osam vrsta sekundarnih metabolita (antocijanini, emodini, fenoli, kumarini, masne kiseline, saponini, steroidi i tanini) u vodenim ekstraktima listova i kore 25 lišćarskih drvenastih vrsta, u okviru 15 porodica, je kvalitativno istraživano brzim fitohemijskim metodama. Prema literaturnim podacima, u ovoj studiji je po prvi put utvrđeno prisustvo šest tipova sekundarnih metabolita $\mathrm{u}$ analiziranim drvenastim vrstama: antocijanini u jednoj vrsti; kumarini i fenoli u po pet vrsta; emodini u šest vrsta; saponini u osam vrsta; te tanini u četiri vrste. Posebnu pažnju u daljnjem istraživanju treba posvetiti Fagus sylvatica L., Populus tremula L., Quercus petraea (Matt.) Liebl., Robinia pseudoacacia L. i Sorbus aria (L.) Crantz. Budući da su preliminarni rezultati ovog istraživanja obećavajući, bilo bi poželjno identificirati aktivna jedinjenja i procijeniti njihovu potencijalnu antimikrobnu i antioksidativnu aktivnost.

Corresponding author:Fatima Pustahija; Faculty of Forestry University of Sarajevo, Zagrebačka 20, 71000 Sarajevo, Bosnia\&Herzegovina; e-mail:: f.pustahija@sfsa.unsa.ba;

\section{ANNEX}


Works of the Faculty of Forestry

University of Sarajevo

No. 1, 2016 (58-73)

Table 1 . The results of phytochemical analyses of secondary metabolites presence by rapid screening methods for analyzed dendro species. The bolded numbers mark presence of SM recorded for the first time to our knowledge.

Tabela 1. Rezultati fitohemijske analize prisustva sekundarnih metabolita pomoću brzih metoda za analizirane drvenaste vrste. Podebljani brojevi označavaju prisustvo uočenog sekundarnog metabolita po prvi put, prema našim saznanjima.

\begin{tabular}{|c|c|c|c|c|c|c|c|c|c|c|c|c|c|c|c|c|c|}
\hline \multirow{2}{*}{$\begin{array}{l}\text { Secondary } \\
\text { metabolite/ } \\
\text { Sekundarni } \\
\text { metabolit } \\
\text { Species and family/ } \\
\text { Vrsta i porodica } \\
\end{array}$} & \multirow{2}{*}{$\begin{array}{l}\text { Plant } \\
\text { part/ } \\
\text { Dio } \\
\text { biljke }\end{array}$} & \multicolumn{2}{|c|}{$\begin{array}{l}\text { Anthocyanins/ } \\
\text { Antocijanini }\end{array}$} & \multicolumn{2}{|c|}{$\begin{array}{c}\text { Coumarins/ } \\
\text { Kumarini }\end{array}$} & \multicolumn{2}{|c|}{$\begin{array}{l}\text { Emodins/ } \\
\text { Emodini }\end{array}$} & \multicolumn{2}{|c|}{$\begin{array}{l}\text { Fatty acids/ } \\
\text { Masne } \\
\text { kiseline }\end{array}$} & \multicolumn{2}{|c|}{$\begin{array}{l}\text { Phenols/ } \\
\text { Fenoli }\end{array}$} & \multicolumn{2}{|c|}{$\begin{array}{c}\text { Saponins/ } \\
\text { Saponini }\end{array}$} & \multicolumn{2}{|c|}{$\begin{array}{l}\text { Steroids/ } \\
\text { Steroidi }\end{array}$} & \multicolumn{2}{|c|}{$\begin{array}{c}\text { Tannins/ } \\
\text { Tanini }\end{array}$} \\
\hline & & OD & LD & OD & LD & OD & LD & OD & LD & OD & LD & OD & LD & OD & LD & OD & LD \\
\hline \multirow{2}{*}{$\begin{array}{l}\text { Acer campestre } \mathrm{L} . \\
\text { Aceraceae }\end{array}$} & L & 0 & 0 & 0 & 1 & 0 & 0 & 0 & 0 & 0 & 1 & 1 & 1 & 0 & 0 & 0 & 0 \\
\hline & B & 0 & 0 & 0 & 0 & 0 & 0 & 0 & 0 & 1 & 1 & 0 & 0 & 0 & 0 & 1 & 1 \\
\hline \multirow{2}{*}{$\begin{array}{l}\text { Acer obtusatum } \\
\text { Waldst \& Kit. ex } \\
\text { Willd. } \\
\text { Aceraceae } \\
\end{array}$} & L & 0 & 0 & 0 & 0 & 0 & 0 & 0 & 0 & 0 & 0 & 0 & 0 & 0 & 0 & 0 & 0 \\
\hline & B & 0 & 0 & 0 & 0 & 0 & 0 & 0 & 0 & 0 & 0 & 1 & 0 & 0 & 0 & 1 & 0 \\
\hline \multirow{2}{*}{$\begin{array}{l}\text { Acer pseudoplatanus } \\
\text { L. } \\
\text { Aceraceae }\end{array}$} & L & 0 & 0 & 0 & 1 & 0 & 0 & 1 & 1 & 1 & 1 & 0 & 0 & 0 & 0 & 0 & 1 \\
\hline & B & 0 & 0 & 0 & 0 & 0 & 0 & 1 & 1 & 1 & 1 & 0 & 0 & 0 & 0 & 0 & 1 \\
\hline \multirow{2}{*}{$\begin{array}{l}\text { Acer tataricum } \mathrm{L} \text {. } \\
\text { Aceraceae }\end{array}$} & L & 0 & 1 & 0 & 0 & 0 & 0 & 1 & 1 & 0 & 0 & 0 & 0 & 0 & 0 & 0 & 1 \\
\hline & B & 0 & 0 & 0 & 0 & 0 & 0 & 0 & 0 & 1 & 0 & 1 & 0 & 0 & 0 & 0 & 0 \\
\hline \multirow{2}{*}{$\begin{array}{l}\text { Carpinus betulus L. } \\
\text { Betulaceae }\end{array}$} & L & 0 & 0 & 0 & 0 & 0 & 0 & 1 & 1 & 1 & 1 & 0 & 0 & 0 & 0 & 0 & 1 \\
\hline & B & 0 & 0 & 0 & 0 & 0 & 0 & 0 & 0 & 0 & 0 & 0 & 0 & 0 & 0 & 0 & 0 \\
\hline
\end{tabular}


Fatima Pustahija, Neđad Bašić

\begin{tabular}{|c|c|c|c|c|c|c|c|c|c|c|c|c|c|c|c|c|c|}
\hline $\begin{array}{l}\text { Clematis vitalba } \mathrm{L} \text {. } \\
\text { Ranunculaceae }\end{array}$ & $\begin{array}{l}\mathrm{L} \\
\mathrm{B}\end{array}$ & 0 & 0 & 0 & 1 & 0 & 0 & 1 & 1 & 1 & 1 & 0 & 0 & 0 & 0 & $\begin{array}{l}0 \\
0 \\
\end{array}$ & 0 \\
\hline $\begin{array}{l}\text { Cornus mas L. } \\
\text { Cornaceae }\end{array}$ & $\begin{array}{l}\mathrm{L} \\
\mathrm{B}\end{array}$ & $\begin{array}{l}0 \\
0 \\
\end{array}$ & 0 & 0 & $\begin{array}{l}0 \\
0 \\
\end{array}$ & $\begin{array}{l}0 \\
0 \\
\end{array}$ & $\begin{array}{l}0 \\
0 \\
\end{array}$ & 1 & $\begin{array}{l}1 \\
0\end{array}$ & 0 & 0 & 0 & 0 & 0 & 0 & $\begin{array}{l}1 \\
0 \\
\end{array}$ & $\begin{array}{l}1 \\
0\end{array}$ \\
\hline $\begin{array}{l}\text { Crataegus monogyna } \\
\text { Jacq. } \\
\text { Rosaceae }\end{array}$ & $\mathrm{L}$ & 0 & 1 & 1 & 0 & 0 & 0 & 0 & 0 & 0 & 0 & 0 & 1 & 0 & 0 & $\begin{array}{l}0 \\
1\end{array}$ & 0 \\
\hline $\begin{array}{l}\text { Daphne mezereum L. } \\
\text { Thymelaeaceae }\end{array}$ & $\begin{array}{l}\mathrm{L} \\
\mathrm{B}\end{array}$ & 0 & 0 & 0 & 1 & 0 & 0 & 0 & 0 & 1 & 1 & 0 & 0 & $\begin{array}{l}0 \\
0\end{array}$ & 0 & $\begin{array}{l}0 \\
0\end{array}$ & 0 \\
\hline $\begin{array}{l}\text { Euonymus europaeus } \\
\text { L. } \\
\text { Celastraceae }\end{array}$ & $\mathrm{L}$ & 0 & 0 & 1 & 0 & 0 & 0 & 0 & 0 & 1 & 1 & 0 & 0 & $\begin{array}{l}0 \\
0\end{array}$ & 0 & $\begin{array}{l}0 \\
0\end{array}$ & 0 \\
\hline $\begin{array}{l}\text { Fagus sylvatica } \mathrm{L} . \\
\text { Fagaceae }\end{array}$ & $\begin{array}{l}\mathrm{L} \\
\mathrm{B}\end{array}$ & 0 & 1 & 0 & 0 & 0 & 0 & 1 & 1 & 1 & $\mathbf{0}$ & 0 & 1 & 0 & 0 & $\begin{array}{l}0 \\
1 \\
\end{array}$ & 0 \\
\hline $\begin{array}{l}\text { Fraxinus ornus } \mathrm{L} . \\
\text { Oleaceae }\end{array}$ & $\begin{array}{l}\mathrm{L} \\
\mathrm{B} \\
\end{array}$ & 0 & 0 & 0 & 1 & 1 & 0 & 1 & 1 & 0 & 0 & 0 & 0 & 0 & 0 & 1 & 1 \\
\hline $\begin{array}{l}\text { Hedera helix } \mathrm{L} . \\
\text { Araliaceae }\end{array}$ & $\begin{array}{l}\mathrm{L} \\
\mathrm{B}\end{array}$ & 1 & 1 & 0 & 1 & 0 & 0 & 0 & 0 & 0 & 1 & 0 & 0 & 0 & 0 & 0 & 0 \\
\hline
\end{tabular}


Preliminary phytochemical screening for secondary metabolites in leaves and bark of 25 broadleaf deciduous species

\begin{tabular}{|c|c|c|c|c|c|c|c|c|c|c|c|c|c|c|c|c|c|}
\hline $\begin{array}{l}\text { Populus tremula } \mathrm{L} \text {. } \\
\text { Salicaceae }\end{array}$ & $\begin{array}{l}\mathrm{L} \\
\mathrm{B} \\
\end{array}$ & 0 & 0 & 0 & 0 & 1 & 0 & 1 & $\begin{array}{l}1 \\
0 \\
\end{array}$ & 1 & 0 & 0 & 0 & 0 & 0 & 1 & 1 \\
\hline $\begin{array}{l}\text { Prunus avium (L.) L. } \\
\text { Rosaceae }\end{array}$ & $\begin{array}{l}\mathrm{L} \\
\mathrm{B} \\
\end{array}$ & $\begin{array}{l}0 \\
0 \\
\end{array}$ & $\begin{array}{l}0 \\
1 \\
\end{array}$ & 0 & $\begin{array}{l}0 \\
0 \\
\end{array}$ & $\begin{array}{l}0 \\
1 \\
\end{array}$ & $\begin{array}{l}0 \\
\mathbf{0} \\
\end{array}$ & 0 & $\begin{array}{l}0 \\
1 \\
\end{array}$ & 0 & 1 & $\begin{array}{l}0 \\
0 \\
\end{array}$ & $\begin{array}{l}0 \\
0 \\
\end{array}$ & $\begin{array}{l}0 \\
0 \\
\end{array}$ & $\begin{array}{l}1 \\
0 \\
\end{array}$ & $\begin{array}{l}0 \\
1 \\
\end{array}$ & 1 \\
\hline $\begin{array}{l}\text { Pyrus pyraster }(\mathrm{L} .) \\
\text { Burgsd. } \\
\text { Rosaceae }\end{array}$ & $\mathrm{L}$ & 0 & 0 & 0 & 0 & 0 & 0 & 0 & 0 & 0 & 0 & 0 & 0 & 0 & 0 & $\begin{array}{l}1 \\
1\end{array}$ & 0 \\
\hline $\begin{array}{l}\text { Quercus petraea } \\
\text { (Matt.) Liebl. } \\
\text { Fagaceae }\end{array}$ & $\begin{array}{l}\mathrm{L} \\
\mathrm{B} \\
\end{array}$ & 0 & 0 & 1 & 0 & 0 & 0 & 0 & 0 & 1 & 0 & 0 & 0 & $\begin{array}{l}0 \\
0 \\
\end{array}$ & 0 & $\begin{array}{l}0 \\
1 \\
\end{array}$ & 0 \\
\hline $\begin{array}{l}\text { Rhamnus fallax } \\
\text { Boiss. } \\
\text { Rhamnaceae }\end{array}$ & $\mathrm{B}$ & 0 & 0 & 0 & 0 & 0 & 0 & 0 & 0 & 1 & 1 & 1 & 1 & 0 & 0 & $\begin{array}{l}0 \\
0 \\
\end{array}$ & 1 \\
\hline $\begin{array}{l}\text { Robinia } \\
\text { pseudoacacia L. } \\
\text { Fabaceae }\end{array}$ & $\mathrm{L}$ & 0 & 0 & 1 & $\mathbf{0}$ & 0 & 0 & 1 & 1 & 0 & 0 & 1 & $\mathbf{0}$ & 0 & 0 & 1 & 1 \\
\hline $\begin{array}{l}\text { Salix caprea } \mathrm{L} . \\
\text { Salicaceae }\end{array}$ & $\begin{array}{l}\mathrm{L} \\
\mathrm{B} \\
\end{array}$ & 0 & 0 & 0 & 0 & 0 & 0 & 1 & 1 & 1 & 1 & 0 & 1 & 0 & 0 & 1 & 1 \\
\hline $\begin{array}{l}\text { Sambucus nigra L. } \\
\text { Adoxaceae }\end{array}$ & $\begin{array}{l}\mathrm{L} \\
\mathrm{B}\end{array}$ & 0 & 1 & 0 & 1 & 0 & 0 & 1 & 1 & 0 & 1 & 1 & $\mathbf{0}$ & 0 & 0 & 0 & 0 \\
\hline
\end{tabular}


Fatima Pustahija, Neđad Bašić

\begin{tabular}{|c|c|c|c|c|c|c|c|c|c|c|c|c|c|c|c|c|c|}
\hline $\begin{array}{l}\text { Sorbus aria (L.) } \\
\text { Crantz } \\
\text { Rosaceae }\end{array}$ & B & 0 & $\begin{array}{l}1 \\
1 \\
\end{array}$ & 0 & 0 & 1 & 0 & 0 & 0 & 0 & 0 & 0 & 0 & 0 & 0 & 0 & 1 \\
\hline $\begin{array}{l}\text { Sorbus aucuparia L. } \\
\text { Rosaceae }\end{array}$ & $\mathrm{L}$ & 1 & $\begin{array}{l}1 \\
0 \\
\end{array}$ & 0 & 1 & 0 & 0 & 0 & 0 & 1 & 1 & 0 & 0 & 0 & 0 & 0 & 1 \\
\hline $\begin{array}{l}\text { Sorbus domestica L. } \\
\text { Rosaceae }\end{array}$ & $\mathrm{L}$ & 0 & $\begin{array}{l}1 \\
1 \\
\end{array}$ & 0 & 0 & 0 & 0 & 0 & 0 & 1 & 1 & 0 & 0 & 0 & 0 & 0 & 0 \\
\hline $\begin{array}{l}\text { Sorbus torminalis } \\
\text { (L.) Crantz } \\
\text { Rosaceae }\end{array}$ & $\mathrm{L}$ & 0 & 0 & 0 & 0 & 0 & 0 & 1 & 1 & 0 & 0 & 0 & 0 & 0 & 0 & 1 & 1 \\
\hline
\end{tabular}

Note : L-leaf; B-bark; 0-lacking; 1-present; OD-our data; LD-literature data.

Napomena: L-list; B-kora; 0-negativan rezultat; 1- pozitivan rezultat; OD-naši podaci; LD-literaturni podaci. 